\title{
GLYCOPYRROLATE AS A SUBSTITUTE FOR ATROPINE IN NEOSTIGMINE REVERSAL OF MUSCLE RELAXANT DRUGS
}

\author{
S. RamamuRThY, M.D., M.H. Shaker, M.D., AND A.P. WiNME, M.D."
}

\section{INTRODUCTION}

Atropine AND scopolamine continue to be the conventional anticholinergic agents for preanaesthetic medication, in spite of the fact that these drugs possess several inherent shortcomings: first of all, their duration of action is so short ${ }^{1}$ that when given in the usual manner prior to anaesthesia and surgery, most of their anticholinergic effect is dissipated by the time the actual induction of anaesthesia takes place. Secondly, the tachycardia which occasionally follows premedication with atropine may be undesirable in some patients, and the arrhythmias which not infrequently follow its use intravenously during anaesthesia may be dangerous and have resulted in death.,3 While scopolamine has much less effect on cardiac rate and rhythm, whether given pre-operatively or intra-operatively, it is also much less effective as a vagolytic drug, particularly with respect to the cardiac vagus. ${ }^{4}$ And thirdly, both of these drugs cross the blood-brain barrier and may result in undesirable, untoward side effects that include mental aberrations and loss of temperature regulation.

Being quaternary ammonium compounds, the synthetic substitutes for the belladonna alkaloids theoretically should rectify several, if not all, of these shortcomings. Because these agents cannot readily pass the blood-brain barrier, central effects are generally lacking. In addition, the quaternary anmonium compounds usually have a more prolonged action than do the natural alkaloids, most of them having a duration of action varying from 4 to 6 hours. Unfortunately all of the synthetic substitutes that have been evaluated as premedicant drugs have produced either excessive tachycardia or an undue incidence of unpleasant side effects, such as dryness of the mouth and blurring of vision. ${ }^{5-7}$

Because of these shortcomings in the synthetic substitutes and because secretions have become less of a problem since the replacement of ether by the newer anaesthetics, atropine and scopolamine have remained as the standard anticholinergic premedicant drugs. However, concem over the inadequacy of these drugs has arisen again in relation to the practice of reversing the effects of non-depolarizing muscle relaxants with neostigmine. Atropine has been given prior to or simultaneously with neostigmine to protect against severe bradycardia or cardiac arrest, but in spite of this several instances of sudden death have been reported following the intravenous administration of neostigmine and atropine in anaesthetized and curarized patients. ${ }^{8-19}$ These deaths have been attributed by most observers to the cholinergic action of neostigmine on the heart, ${ }^{8-18}$ by others to the sudden sympathetic predominance, , whether due to adrenergic stimulation or cholinergic block, and by

'Departments of Anesthesiology, Cook County Hospital and University of Illinois Hospital, Chicago, Illinois. 
still others to initial central vagal stimulation produced by atropine, which would potentiate the cholinergic action of neostigmine. ${ }^{14}$ This disagreement as to the mechanisms by which arrhythmias are evoked by reversal have led to disagreement as to the means by which reversal should be carried out. While some anaesthetists have preferred to inject atropine several minutes preceding the injection of neostigmine, others have preferred the simultaneous injection of the two drugs. Both techniques have their pitfalls: as stated earlier, during anaesthesia the intravenous injection of atropine alone is known to be followed occasionally by serious arrhyth. mias, the frequency of which depends upon the type of anaesthetic being administered at the time of injection. Jones, Deutsch and Turndorf found that during halothane anaesthesia there was a 17 per cent incidence of ventricular arrhythmias following the intravenous injection of $0.4 \mathrm{mg}$ of atropine, and that this incidence increased to 54 per cent with cyclopropane; whereas arrhythmias did not occur to any appreciable extent in patients anaesthetized with nitrous oxide. ${ }^{3}$ The incidence of arrhythmias is also less with any anaesthetic agent if the atropine is given in small increments rather than in a large bolus. However, even using this incremental technique, Eger has reported one case of ventricular fibrillation following the intravenous injection of $0.2 \mathrm{mg}$ of atropine during cyclopropane anaesthesia, a dose which is considered to be safe. ${ }^{2}$

In order to determine which of these two techniques of reversal was safer, Ovassapian studied the circulatory effects of atropine and neostigmine when these were. administered sequentially 3 to 4 minutes apart, slowly and simultaneously over one and one half minutes, and rapidly and simultaneously within 11 seconds. He found no serious change in cardiac rate, rhythm, or arterial pressure with any of thest techniques, ${ }^{15}$

However, he did find that when atropine was given first and followed by neostigmine, the degree and duration of tachycardia was more marked than when the two drugs were given together; and though a delayed bradycardia was slightly more common in the patients receiving the combination of drugs rapidly, there was no instance of profound or sudden bradycardia or of serious arrhythmia. On the basis of these data, Ovassapian concluded that the rational method of administering atropine and neostigmine for reversal of relaxant drugs was in combination, in a ratio of $0.4 \mathrm{mg}$ of atropine for each milligram of neostigmine.

While Ovassapian concerned himself with determining the relationship between the way in which atropine and neostigmine were given and the resulting heart rate, the present authors question the selection of atropine as the anticholinergic drug of choice. A review of the extensive literature on the belladonna alkaloids and their synthetic and semi-synthetic substitutes indicated that one of the newer quaternary ammonium compounds, glycopyrrolate, shown in numerous studies to have unequalled potency with respect to gastric anticholinergic activity with virtually no undesirable cardiac or other side effects, had never been utilized in anaesthesia, though it was available in parenteral form.

Because of the proven efficacy of this agent in decreasing the volume and acidity of gastric secretion, Watson ${ }^{16}$ reported in 1969 on the use of glycopyrrolate in the pre-operative period to raise the $\mathrm{pH}$ of gastric juice so that unexpected aspiration during or after elective tonsillectomy was virtually without sequelae. During the 
course of these studies he was so impressed with the anticholinergic potency of glycopyrrolate and its freedom from side effects that he proposed its use as replacement for atropine in preanaesthetic medication and for neostigmine reversal of curare. Watson suggested that the dose be half that of atropine.

The present study was undertaken (1) to determine whether glycopyrrolate does offer any advantage over atropine as an anticholinergic drug for the reversal of curare with neostigmine; (2) to determine whether the dose proposed by Watson was optimal; and (3) to determine whether the sequence of anticholinergic and cholinergic drug injection suggested by Ovassapian was optimal.

\section{Methods and Materials}

Eighty-five healthy adult patients of both sexes were studied during anaesthesia and surgery. They were selected solely because they were free from cardiopulmonary disease. All of the patients had been premedicated with atropine $0.4 \mathrm{mg}$, which was given with an appropriate dose of either morphine or meperidine. While the type of surgical procedure varied widely, the anaesthetic maangement was standardized. Following induction with a "sleep dose" of thiopentone, increasing increments of halothane were introduced with nitrous oxide and oxygen, 2 liters of each. When the patient was in a surgical plane of anaesthesia, succinylcholine was administered intravenously and the trachea was intubated.

Thereafter anaesthesia was maintained with 1 to 1.5 per cent halothane in 50 per cent nitrous oxide and 50 per cent oxygen; relaxation was provided with incremental doses of d-Tubocurarine as needed and ventilation was assisted or controlled manually throughout. Following the completion of surgery, but prior to the reversal of the curare, halothane was discontinued for at least 10 minutes prior to the beginning of the study, during which time nitrous oxide 70 per cent and oxygen 30 per cent were continued and ventilation was assisted or controlled. To avoid extraneous stimuli the trachea and nasopharynx were not suctioned prior to reversal. Ten minutes after the discontinuance of halothane, arterial blood was drawn for blood gas analysis, and when it was determined that $\mathrm{pH}, \mathrm{PaO}_{2}$ and $\mathrm{PaCO}_{2}$ were all within normal limits, the drugs under study were administered intravenously. Before, during; and after the injection of the test drugs, the electrocardiogram was monitored continuously with a direct writer, to follow changes in cardiac rate and rhythm for 10 minutes post-injection. To allow precise determination of the exact cardiac rate following the injection, the $\mathrm{H}-\mathrm{R}$ interval was measured at the end of each minute and the heart rate determined from the table of Ashman and Hull. In addition, blood pressure was determined with a sphygmomanometer at the end of each minute for 10 minutes. At the end of 10 minutes the studies were discontinued and endotracheal and oropharyngeal suction was performed to determine the amount of secretions present.

Since the present study had three objectives, it was divided into three phases. In Phase I, to determine the optimal ratio of glycopyrrolate/neostigmine, 25 of the patients were divided into five equal groups. Reversal was achieved in all patients by using an intermediate fixed dose of $2 \mathrm{mg}$ of neostigmine, while the dose of glycopyrrolate injected in combination with the neostigmine differed in each group - one 
group receiving $0.2 \mathrm{mg}$, the next $0.3 \mathrm{mg}$, the next $0.4 \mathrm{mg}$, the next $0.5 \mathrm{mg}$, and the last $0.6 \mathrm{mg}$. In Phase II, to compare the protection afforded by glycopyrrolate in the "optimal ratio" to that afforded by atropine in the usual ratio, when both were given in combination with a $3 \mathrm{mg}$ maximal dose of neostigmine, 40 patients were divided into two groups. One of these groups received $3 \mathrm{mg}$ of neostigmine in combination with $0.6 \mathrm{mg}$ of glycopyrrolate, while the other group received $3 \mathrm{mg}$ of neostigmine with $1.2 \mathrm{mg}$ of atropine. In Phase III, to determine the optimal sequence of glycopyrrolate-neostigmine injection, 20 patients were divided into two groups on the basis of the way in which the two drugs were given. In one group the injection of neostigmine preceded the injection of glycopyrrolate by 30 seconds, while in the other group injection of neostigmine preceded injection of glycopyrrolate by 60 seconds. The results in these two groups were compared with the group in Phase I (ultimately shown to be the recipients of the "optimal ratio" of glycopyrrolate/neostigmine) to determine whether the time sequence of the injections had a significant effect on the maximal and minimal changes in pulse rate.

\section{Results}

The data obtained in Phase $I$, in which patients received a $2 \mathrm{mg}$ fixed dose of neostigmine and a variable dose of glycopyrrolate, are presented in tabular form in Table I and are displayed graphically in Figure 1. In all groups of patients, it may be seen that the injection of the mixtare is followed immediately by an increase in pulse rate regardless of the dose ratio. This increase is roughly proportional to the dose of glycopyrrolate and reaches a maximum at the end of 1 minute, after which there is a continuous progressive decrease in pulse rate. In all groups except that receiving glycopyrrolate $0.6 \mathrm{mg}$, the heart rate fell below control values within the

TABL I: PHASE I

CHAHGE IM HEART RATE (BEATS PER MIN, $\pm \$$, E.)

\begin{tabular}{|c|c|c|c|c|c|c|c|c|c|c|}
\hline & & EFOLEO & HE GYCO & BROLAIE & MEOST & aHiNE & XTUAFE & & & \\
\hline AGEMTS IMUACTED & 1 min. & 2 MiE. & 3 mint. & 4 min. & $5 \mathrm{~min}$ & $6 \mathrm{Hin}$ & 2 Min & B win. & g Men, & $10 \mathrm{Min}$ \\
\hline 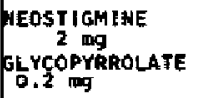 & $\begin{array}{l}+2.3 \\
+2.6\end{array}$ & $\begin{array}{l}-1.2 \\
\pm 3.7\end{array}$ & $\begin{array}{l}-4.5 \\
\pm 3.3\end{array}$ & $\begin{array}{l}-5.6 \\
\pm 2.4\end{array}$ & $\begin{array}{l}-8.4 \\
\pm 2.4\end{array}$ & $\begin{array}{l}-9.6 \\
\pm 2.5\end{array}$ & $\begin{array}{l}-8.7 \\
\pm 1.6\end{array}$ & $\begin{array}{r}-10.6 \\
\pm 2.1\end{array}$ & $\begin{array}{l}-9.7 \\
+2.0\end{array}$ & $\begin{array}{l}-10.5 \\
\pm 2.3\end{array}$ \\
\hline 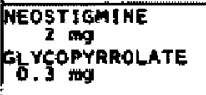 & $\begin{array}{l}+6.2 \\
\pm 3.2\end{array}$ & $\begin{array}{l}-0.5 \\
\pm 1.5\end{array}$ & $\begin{array}{l}-4.6 \\
\pm 1.9\end{array}$ & $\begin{array}{l}-4.5 \\
\pm 4.1\end{array}$ & $\begin{array}{l}-7.2 \\
\pm 4.5\end{array}$ & $\begin{array}{l}-7.6 \\
\pm 4.9\end{array}$ & $\begin{array}{l}-7 \\
45.0\end{array}$ & $\begin{array}{l}=12 \\
\pm 1.0\end{array}$ & $\begin{array}{r}-10.7 \\
\pm 3.5\end{array}$ & $\begin{array}{r}-13.0 \\
\pm 12.4\end{array}$ \\
\hline 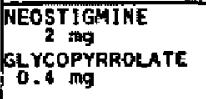 & $\begin{array}{l}+8.4 \\
\pm 1.3\end{array}$ & $\begin{array}{l}+7.4 \\
\pm 1.9\end{array}$ & $\begin{array}{l}+4.4 \\
\pm 1.4\end{array}$ & $\begin{array}{l}+2.6 \\
\pm 2.3\end{array}$ & $\begin{array}{l}+0.6 \\
\pm 2.4\end{array}$ & $\begin{array}{l}-1 \\
\pm 1.6\end{array}$ & $\begin{array}{r}42,2 \\
\pm 1.8\end{array}$ & $\begin{array}{l}-3.6 \\
\pm 1.6\end{array}$ & $\begin{array}{l}-4 \\
\pm 1.7\end{array}$ & $\begin{array}{l}=5.2 \\
\pm 2.2\end{array}$ \\
\hline $\begin{array}{l}\text { WEOSSTIGPJNE } \\
2 \text { mg } \\
\text { SLCOPYRROLATE } \\
\text { Y } 5 \text { mg }\end{array}$ & $\begin{array}{r}+12.6 \\
+\quad 3.2\end{array}$ & $\begin{array}{r}+11.0 \\
+3.2\end{array}$ & $\begin{array}{l}+9 \\
\pm 3.4\end{array}$ & $\begin{array}{l}+6.6 \\
\pm 2.5\end{array}$ & $\begin{array}{l}91.0 \\
\pm 3.0\end{array}$ & $\begin{array}{l}+2.5 \\
\pm 2.6\end{array}$ & $\begin{array}{l}+0.4 \\
22,7\end{array}$ & $\begin{array}{l}-1.4 \\
22.4\end{array}$ & $\begin{array}{l}-2.2 \\
\pm 2.2\end{array}$ & $\begin{array}{l}-3 \\
\pm 2.0\end{array}$ \\
\hline 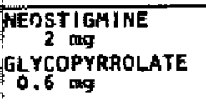 & $\begin{array}{l}+23.2 \\
\pm 4.9\end{array}$ & $\begin{array}{l}+20.8 \\
\pm 1.9\end{array}$ & $\begin{array}{l}+18.8 \\
\pm 2.6\end{array}$ & $\begin{array}{l}+16.2 \\
\pm 2.6\end{array}$ & $\begin{array}{l}+14.6 \\
+3.0\end{array}$ & $\begin{array}{r}+12.0 \\
+2.9\end{array}$ & $\begin{array}{l}+11.6 \\
\pm 3.0\end{array}$ & $\begin{array}{l}+10.6 \\
+2.6\end{array}$ & $\begin{array}{r}+11.4 \\
\pm 3.6\end{array}$ & $\begin{array}{l}+9.2 \\
\pm 3.1\end{array}$ \\
\hline
\end{tabular}




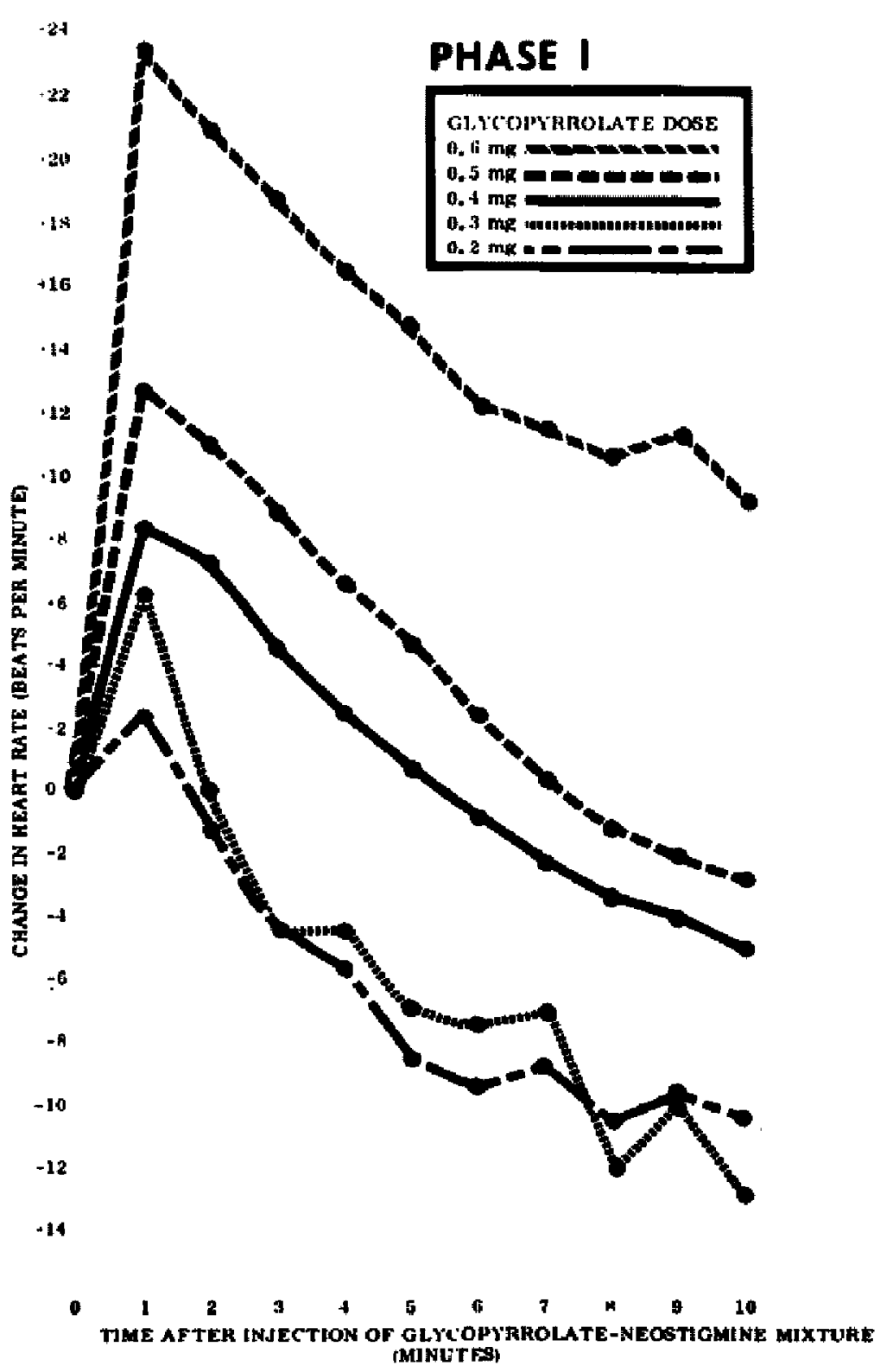

Froure 1. Sequential changes in heart rate in five groups of five patients each, all of whom received $2 \mathrm{mg}$ of neostigmine. Only the dose of glycopyrolate, which was injected simultaneously with the neostigmine, differed in each group. 
10 minute period of study. The final degree of bradycardia was inversely proportional to the dose of glycopyrrolate.

At the end of the 10-minute study period when endotracheal and oropharyngeal suctioning was performed, secretions were negligible in all except the group receiving glycopyrrolate $0.2 \mathrm{mg}$. In this latter group, while secretions were present in greater quantity, they were neither excessive nor a problem. Following suctioning and removal of the endotracheal tube, all groups showed an increase in pulse rate; the magnitude of which was apparently not related to the dose of glycopyrrolate.

The data obtained in Phase II, which compared the anticholinergic efficacy of glycopyrrolate $0.6 \mathrm{mg}$ with that of atropine $1.2 \mathrm{mg}$ when each was given simultaneously with $3 \mathrm{mg}$ of neostigmine, are presented in Table II. Figure 2, which displays the data graphically, again shows that the maximal increase in pulse rate occurred 1 minute after injection, but the maximal increase in pulse rate following the glycopyrrolate mixture is 56 per cent less than that following the atropine mixture. The difference is highly significant $(p<.01)$. After the first minute the pulse rate decreased progressively in both groups, and after 3 minutes there was no longer a significant difference in the chronotropic effect of the two drugs. After 5 to 6 minutes both groups showed a similar decrease in pulse rate below the pre-injection levels until they stabilized at 5 to 6 beats per minute less than the preinjection pulse rates.

Following the 10-minute period of study, when the patients were suctioned, secretions were again virtually absent in the group of patients reversed with the glycopyrrolate-neostigmine mixture while in the group reversed with the atropineneostigmine mixture secretions were frequently copious and sometimes troublesome.

The data obtained in Phase III, compared the chronotropic effects of giving neostigmine simultaneously with glycopyrrolate, 30 seconds before glycopyrrolate, or 60 seconds before glycopyrrolate. This is presented in Table III. Figure 3 displays graphically the evoked changes in pulse rate. Group I represents the patients in Phase I, who received neostigmine $2 \mathrm{mg}$ and glycopyrrolate $0.4 \mathrm{mg}$ simultaneously. This evoked a peak increase in pulse rate of 8 beats per minute by the end of one minute. After this time the pulse rate dropped to the control value by the end of the 5 th minute, and then continued to decrease until it reached a maximal decrease of 6 beats per minute at the end of 11 minutes.

TABLE I 1; PHASE II

CHAMGE IM HEART RATE (BEATS PER HIM, $\pm S, E$, )

\begin{tabular}{|c|c|c|c|c|c|c|c|c|c|c|}
\hline \multirow[b]{2}{*}{ AEEMTS MHECTEn } & \multicolumn{10}{|c|}{ 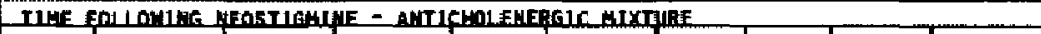 } \\
\hline & $1 \mathrm{mLn}$. & $2 \mathrm{~min}$ & $3 \mathrm{~min}$. & $4 \min$. & $5 \mathrm{~min}$ & 6 min. & $7 \mathrm{~min}$ & a 1 in & 9 min. & $10 \mathrm{nin}$. \\
\hline 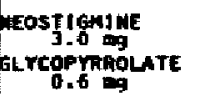 & $\begin{array}{l}+11.35 \\
\pm 2.0\end{array}$ & $\begin{array}{l}+7.9 \\
\pm 2.3\end{array}$ & $\begin{array}{r}+4.9 \\
\pm 2.2\end{array}$ & $\begin{array}{l}+2.35 \\
\pm 2.3\end{array}$ & $\begin{array}{l}+0.7 \\
+2.2\end{array}$ & $\begin{array}{l}-0.5 \\
\pm 2.4\end{array}$ & $\begin{array}{l}-2.4 \\
\pm 2.4\end{array}$ & $\begin{array}{l}-4.0 \\
\pm 2.7\end{array}$ & $\begin{array}{l}-4.9 \\
+2.9\end{array}$ & $\begin{array}{l}-4.1 \\
\pm 3.0\end{array}$ \\
\hline 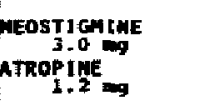 & $\begin{array}{l}+25.9 \\
\pm 1.2\end{array}$ & $\begin{array}{l}+18.9 \\
\pm 3.4\end{array}$ & $\begin{array}{l}+9.8 \\
\pm 2.8\end{array}$ & $\begin{array}{l}+5.5 \\
\pm 2.6\end{array}$ & $\begin{array}{l}+2.4 \\
\pm 2.2\end{array}$ & $\begin{array}{l}+0.6 \\
\pm 2.2\end{array}$ & $\begin{array}{l}-1.6 \\
\pm 2.2\end{array}$ & $\begin{array}{l}-4.0 \\
\pm 2.4\end{array}$ & $\begin{array}{l}-4.0 \\
\pm 2.9\end{array}$ & $\begin{array}{l}.5 .2 \\
\pm 2.1\end{array}$ \\
\hline
\end{tabular}




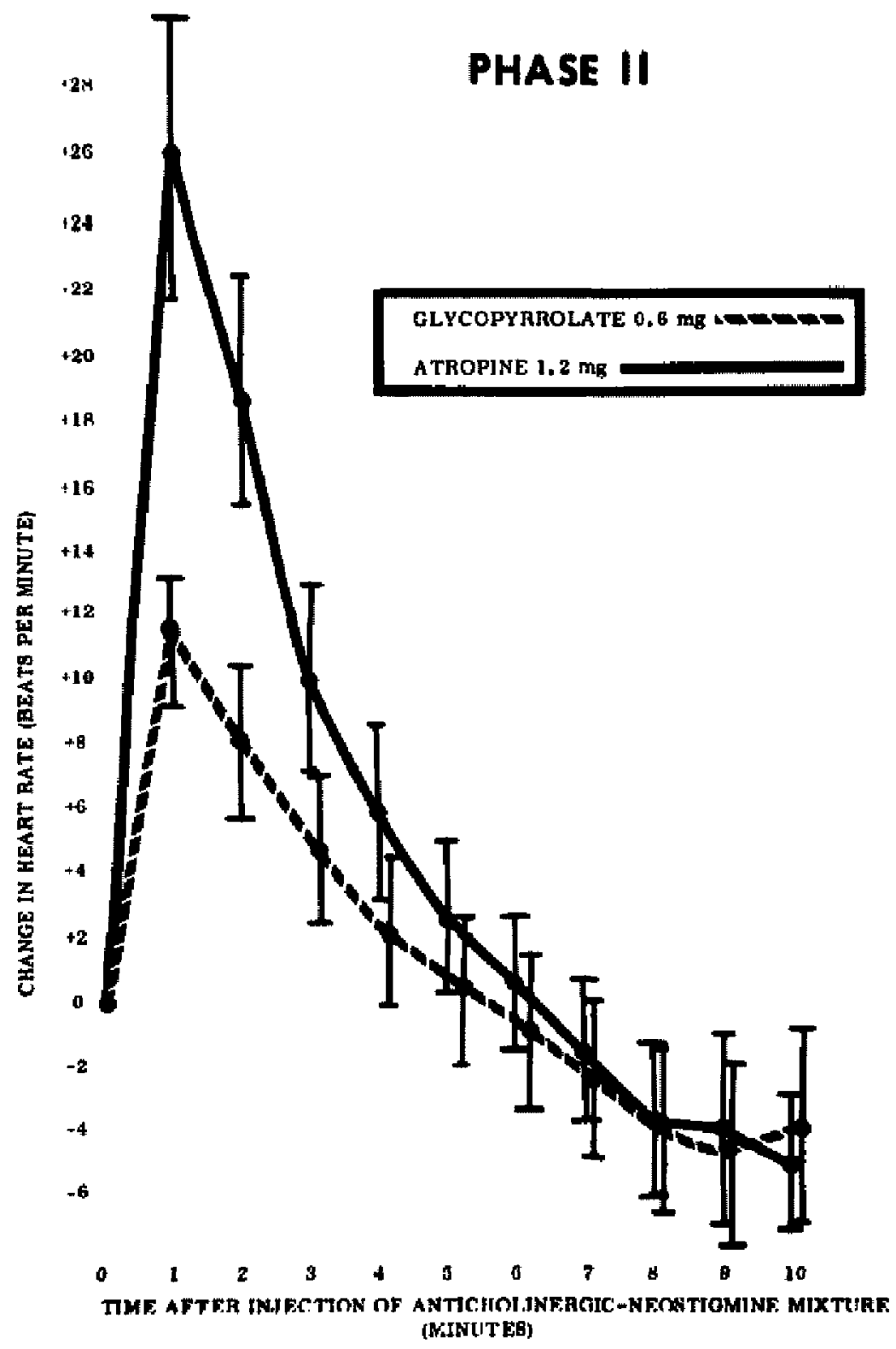

Figure 2. Sequential changes in heart rate in two groups of 20 patients each, one group receiving $3 \mathrm{mg}$ of neostigmine mixed with $0.6 \mathrm{mg}$ of glycopytrolate and the other receiving 3 $\mathrm{mg}$ of neostigmine mixed with $1.2 \mathrm{mg}$ of atropine. The vertical bars represent the standard error of the means. 
In Group II there was a 30 second interval between the injection of neostigmine $2 \mathrm{mg}$ and the injection of glycopyrrolate $0.4 \mathrm{mg}$. During this interval the pulse rate just began to fall. Immediately following the injection of the glycopyrrolate, there was an increase in pulse rate of 7 beats in the first minute. Thereafter there was a continuous fall in the pulse rate which paralleled that seen in Group I and reached a maximum decrease of 7 beats per minute less than control after 10 minutes. In Group III, there was a 60 -second interval between the injection of the neostigmine $2 \mathrm{mg}$ and the injection of the glycopyrolate $0.4 \mathrm{mg}$. During this time the pulse rate decreased 7 beats per minute. Immediately following the injection of glycopyrrolate, the pulse rate increased, reaching almost 2 beats per minute above the preinjection level at 1 minute and a peak of 3 beats per minute above the control level at 2 minutes. Thereafter, the progressive decline in pulse rate paralleled those seen in Groups I and II, with a final decrease in rate to 8 beats per minute less than control.

At the end of the study period when the endotracheal tubes of all patients were suctioned, the amount of secretions was negligible in all three groups. In addition, it was noted that following suctioning and extubation, the pulse rate increased in all three groups in a similar manner.

None of the patients in Phase I or Phase III exhibited any arrhythmias, other than the mild increases and decreases in rate described above. In Phase II, while none of the patients exhibited serious arrhythmias, one patient in the group receiving the glycopyrrolate-neostigmine mixture showed transient nodal rhythm, and three patients in the group receiving the atropine-neostigmine mixture exhibited the same arrhythmia. None of the patients in any of the three phases exhibited increase or decrease in systolic pressure exceeding 10 to $20 \mathrm{~mm} \mathrm{Hg}$.

\section{Discussion}

Until about 1951 in England and in Europe it was common practice to administer atropine and neostigmine simultaneously for reversal of neuromuscular blockade produced by curare. However, in 1949 the first three reports of cardiac arrest associated with this practice appeared, all occurring in patients in whom anaesthesia was maintained by cyclopropane. ${ }^{8}$ In light of work demonstrating an initial slowing effect on the heart of subcutaneous atropine, ${ }^{16}$ it was suggested that even

TA BLE III: PHASE III

CHANGE IN MEART RATE (BEATS PER MIN, \pm S.E.)

\begin{tabular}{|c|c|c|c|c|c|c|c|c|c|c|c|c|c|}
\hline & \multicolumn{13}{|c|}{$\begin{array}{l}\text { TIME AF TER } \\
\text { HEFOSTIGMIME } 2 \text { MG }\end{array}$} \\
\hline & 30 seccs. & 1 mint & $1 \mathrm{~min}$ & 2 Hin & $3 \mathrm{mLn}$ & $4 \mathrm{~min}$. & $5 \mathrm{M1m}$ & $6 \mathrm{Min}$ & $7 \operatorname{Min}$ & $8 \mathrm{Min}$ & $9 \mathrm{~min}$ & 10 min & 110 \\
\hline EROUP $E$ & - & - & $\begin{array}{l}+8.4 \\
\pm 1.3\end{array}$ & +7.4 & $2+4-4$ & $\begin{array}{l}+2.6 \\
\pm 2.3\end{array}$ & \pm 0.6 & \pm 1.6 & $\begin{array}{l}-2.2 \\
\pm 1.8\end{array}$ & $\begin{array}{l}-1.6 \\
\pm 1.8\end{array}$ & -4 & $\pm+5+2$ & $\begin{array}{l}+6 \\
+2.0 \\
\end{array}$ \\
\hline GROUP II & $\begin{array}{l}-0.5 \\
\pm 0.2\end{array}$ & $:$ & $\begin{array}{l}+6.7 \\
\pm 2.6\end{array}$ & $\begin{array}{l}+5.9 \\
-2.0\end{array}$ & $\$ 4.5$ & $\begin{array}{l}+2.6 \\
\pm 1.7\end{array}$ & 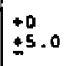 & $\begin{array}{l}-1.9 \\
-1.5\end{array}$ & $\begin{array}{l}-4.2 \\
\pm 1.3\end{array}$ & 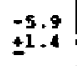 & $\begin{array}{l}-6.8 \\
=1-7\end{array}$ & $\begin{array}{l}-7-3 \\
\pm 1+3\end{array}$ & $\begin{array}{l}-7 \\
\pm 1+2\end{array}$ \\
\hline snotup EII & - & $\begin{array}{r}-6.4 \\
\pm 2.3\end{array}$ & $\begin{array}{l}+1.7 \\
\pm 2.1\end{array}$ & $\begin{array}{l}+2.7 \\
\pm 2+3\end{array}$ & $\begin{array}{l}+0.9 \\
\pm 2.4\end{array}$ & $\begin{array}{l}-0.5 \\
\pm 2.6\end{array}$ & $\begin{array}{l}-2.0 \\
\pm 2.7\end{array}$ & $\begin{array}{l}-3.4 \\
\pm 2.4\end{array}$ & $\begin{array}{l}-4.6 \\
\pm 2.9\end{array}$ & $\begin{array}{l}-7.0 \\
\pm 2.9\end{array}$ & $\begin{array}{l}-7.9 \\
\pm 2.9\end{array}$ & $\begin{array}{l}-8.2 \\
-2.9\end{array}$ & $\begin{array}{l}-8 \\
\pm 3.7\end{array}$ \\
\hline
\end{tabular}




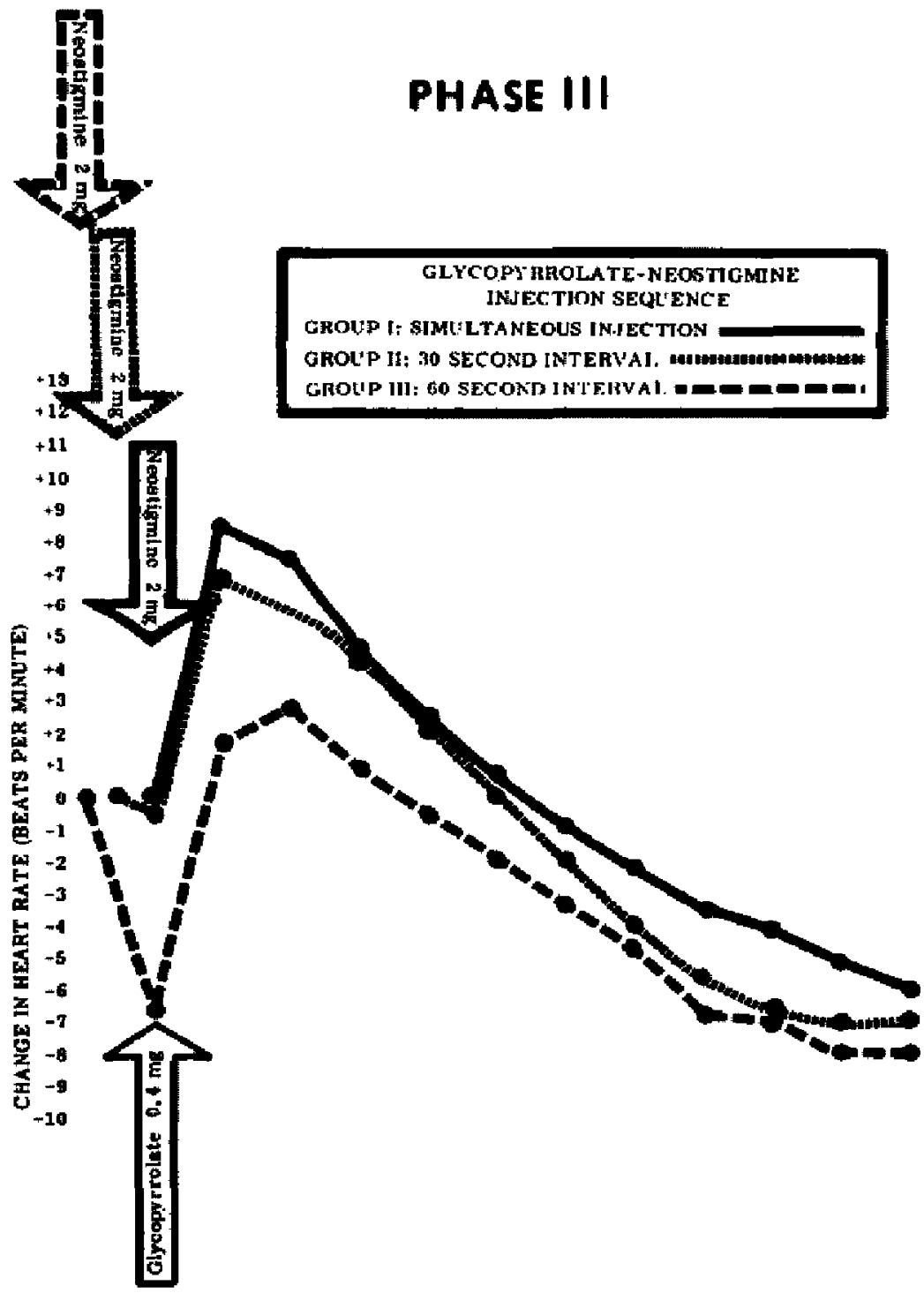

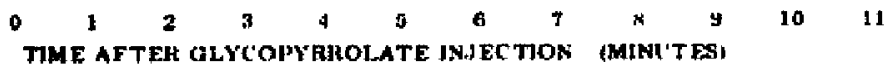

Figure 3. Sequential changes in heart rate when neostigmine $2 \mathrm{mg}$ and glycopyrrolate 0.4 mig were injected simultaneously, 30 seconds apart, and 60 seconds apart. 
when given intravenously it might produce an initial slowing which would transiently enhance the bradycardia caused by neostigmine and be conducive to cardiac arrest. Hunter ${ }^{17}$ however, showed that intravenous atropine did not cause an initial slowing but an immediate tachycardia and that the effect of $1.3 \mathrm{mg}$ of atropine with 2.5 ming of neostigmine produced an initial tachycardia followed by bradycardia, a sequence which the present study has shown to be similar to that following the simultaneous injection of neostigmine and glycopyrrolate. Baraka ${ }^{18}$ has explained the mechanism by which atropine always produces tachycardia before the neostigmine produces bradycardia, on the basis that atropine molecules (and presumably other anticholinergic molecules) attach themselves directly to the cardiac cholinergic receptors, while neostigmine has no direct effect on these receptors. Neostigmine acts indirectly by inhibiting the hydrolysis of acetycholine and promoting the accumulation of these molecules which then compete with the atropine already present at cholinergic receptors.

If an anticholinergic drug is given to protect against excessive cholinergicinduced bradycardia, in view of the biphasic chronotropic effect of the mixture, it must also not cause undue tachycardia prior to the onset of action of the cholinergic drug. It would appear from Figure 1 that of the combinations of glycopyrrolate given together with $2 \mathrm{mg}$ of neostigmine, a dose of $0.4 \mathrm{mg}$ is the best compromise, with a peak tachycardia represented by an increase of pulse rate of only 8 beats per minute and a subsequent reduction of only 5 beats per minute. Thus it would appear that the optimal ratio of glycopyrrolate to neostigmine would be $0.2 \mathrm{mg}$ of glycopyrrolate for each $1 \mathrm{mg}$ of neostigmine. This implies a potency about twice that of atropine, since it is currently recommended that for each $\mathrm{mg}$ of neostigmine injected, $0.4 \mathrm{mg}$ of atropine should be utilized. ${ }^{1 \mathrm{~B}}$ However, to offer a meaningful advantage over atropine, any anticholinergic substitute must present more than a simple increase in $\mathrm{mg}$ for $\mathrm{mg}$ potency. That glycopyrrolate offers such an advantage is illustrated in Figure 2, which demonstrates clearly that the protection afforded by glycopyrrolate $0.6 \mathrm{mg}$ against the development of severe bradycardia following neostigmine $3 \mathrm{mg}$ is virtually identical to that afforded by atropine $1.2 \mathrm{mg}$, while the tachycardia evoked by glycopyrrolate is less than half that evoked by an equally anticholinergic dose of atropine.

In attempting to settle the recurrent controversy as to whether neostigmine was safer if preceded by atropine or if mixed with atropine, Ovassapian ${ }^{15}$ demonstrated that the degree of tachycardia was almost twice as great when atropine was given before neostigmine than it was when atropine was given together with neostigmine. If the initial tachycardia when the drugs are given together is due to the fact that the onset of the cholinergic action of neostigmine, albeit delayed, interferes with the continued rise in pulse due to atropine, then it is not surprising that when atropine is given alone as pre-treatment, without this antagonistic effect the unopposed action of atropine results in an even greater heart rate. It would seem to follow that, since there is a delay in the onset of action of the cholinergic drug, if the administration of the anticholinergic drug were delayed for the exact time necessary for the appearance of the cholinergic action of neostigmine perhaps the onset of action of both would now be "in phase". They 
should thus better antagonize each other and further minimize the peaks of tachycardia and bradycardia. Figure 3, which represents Phase III of the study, indicates that as one varied the time by which the injection of glycopyrrolate was preceded by neostigmine from 0 to 30 to 60 seconds, there was a proportionate decrease in the degree of tachycardia produced by the glycopyrrolate, apparently because increasing time was allowed for the onset of action of neostigmine. It would appear from these curves that at 30 seconds following injection of neostigmine alone cholinergic activity had just begun, while at 60 seconds it was significant ( $P<.001$ ); so it would appear that approximately 45 seconds is required for the negative chronotropic effect of neostigmine to become apparent.

From the above data it would appear that when equipotent anticholinergic doses of glycopyrrolate and atropine are given simultaneously with neostigmine, the reason that glycopyrrolate causes less tachycardia may be related to the fact that this drug has a slower onset of action than atropine, so that the anticholinergic and cholinergic effects of the two drugs have a more similar (though not identical) time of onset. It is interesting to speculate that such a difference in onset might be due to the fact that atropine, being a tertiary amine and hence markedly lipophilic, crosses all cell membranes immediately after injection and even crosses the blood-brain and placental barriers, while glycopyrrolate, being a quaternary ammonium compound and carrying a charge, does not cross cell membranes as rapidly and, in fact, does not cross the blood-brain or placental barrier at all. While this is an attractive hypothesis, it does not explain the fact that the quaternary ammonium derivatives of both atropine and scopolamine, while incapable of crossing the blood-brain and placental barriers, cause an even greater increase in pulse than either of the tertiary amines. ${ }^{5,20}$

The present study would seem to allow the following conclusions: The protection afforded by glycopyrrolate against the development of severe bradycardia following the use of neostigmine for reversal of muscle relaxant drugs is almost identical with that afforded by atropine. However, glycopyrrolate produces significantly less tachycardia than atropine. In view of the fact that there were no serious cardiac arrhythmias associated with its use and no pressor or depressor responses evoked, and in view of the fact that glycopyrrolate appeared to be the better antisialogogue, it would seem that glycopyrrolate is a substitute for atropine and is safer than atropine when used with neostigmine in reversal of nondeploarizing muscle relaxants. The appropriate dose appears to be $0.2 \mathrm{mg}$ of glycopyrrolate for each $1 \mathrm{mg}$ of neostigmine to be administered, and the proper technique to be simultaneous injection.

Glycopyrrolate would also seem to offer several theoretical advantages over atropine and scopolamine for a preanaesthetic medication. Being a quatemary ammonium compund, glycopyrrolate does not cross the blood-brain barrier and so should present none of the central effects associated with the use of atropine and scopolamine. Furthermore, the duration of action of glycopyrrolate is 4 to 6 hours, as compared to one of one and one-half hour for atropine and scopolamine. This is important not only to minimize secretions and prevent the occurrence of laryngospasm, bronchospasm, and cardiovascular reflexes during surgery, but to reduce even further the possibility of producing of arrhythmias by the subsequent 
injection of an anticholinergic drug as a part of the reversal of muscle relaxants. The occurrence of arrhythmias is significantly reduced when the parasympatholytic activity of the anticholinergic premedication is still present when a second injection is made during anaesthesia. ${ }^{4}$ Finally, it has been our experience that the awake patient who has received glycopyrrolate does not complain of unpleasant side effects so common with atropine or scopolamine.

Obviously the usefulness of glycopyrrolate as a preanaesthetic must await further studies; but certainly there is no better way to test anticholinergic activity than to determine the protection afforded against a cholinergic challenge. While from the data obtained in this study, we can only advocate the use of glycopyrrolate in combination with neostigmine for reversal of neuromuscular blockade, we predict that it will also prove to be a superior premedicant.

\section{SUMMARY}

A controlled study was undertaken in man to evaluate glycopyrrolate as a substitute for atropine in anaesthesia by determining the relative ability of the two drugs to protect against the cholinergic challenge provided by neostigmine administered at the conclusion of anaesthesia for reversal of neuromuscular blockade. Results indicate that glycopyrrolate offers the same protection against neostigmine-induced bradycardia as atropine with a marked reduction in the magnitude of the initial tachycardia. The dose of glycopyrrolate required to do this is $0.2 \mathrm{mg}$ for each $1 \mathrm{mg}$ of neostigmine administered, which is half the dose of atropine required for the same purpose.

\section{RÉSUMÉ}

Nous avons fait, chez l'homme, une étude avec témoin pour déterminer si le glycopyrrolate pourrait remplacer l'atropine en anesthésie; l'étude a porté sur l'habilité relative des deux médicaments de protéger contre la prédominance cholinergique produite par l'administration de néostigmine à la fin de l'anesthésie pour corriger le blocage neuromusculaire. Les résultats démontrant que le glycopyrrolate offre la même protection que l'atropine contre la bradycardie produite par la néostigmine et limportance de la tachycardie initiale est de beaucoup réduite. La dose de glycopyrrolate requise pour obtenir cet effet est de $0.2 \mathrm{mg}$ pour chaque mg de néostigmine donné, ce qui śquivaut à la moitié de la dose d'atropine nécessaire pour obtenir le même effet.

\section{REFERENCES}

1. Wangenman, C.P. \& HAWr, M.H. The effects of morphine, atropine and scopolamine on human subjects. Anesthesiology 3: 24-36 (1942).

2. EcER, E.I. Atropine, scopolamine and related compounds. Anesthesiology 23; 365-383 (1962).

3. Jowes, R.E., DEurscer, $S$, \& TuRnnonF, $F$. Effects of atropine on cardiac rhythm is conscious and anesthetized man. Anesthesiology 22: 67-73 (1961).

4. Orkn, L.T., Bencman, P.S., d NATHanson, M. Effect of atropine, scopolamine and meperidine on man. Anesthesiology 17; 30-37 (1956). 
5. Trotit, W. \& Anriani, J. A comparison of the belladonna alkaloids and certain synthetic parasympatholytic drugs. Surgery 44: 515-519 (1958).

6. Rumex, H.M. \& Schre, F.C. Letter to the Editor (Current Comment): Anesthesiology 16: 653-654 (1955).

7. Stephen, C.R., Bowers, M.A., Nonwill, W.K, \& Martm, R.C. Anticholinergic drugs in preanesthetic medication. Anesthesiology $17: 303-313$ (1956).

8. MacnNiosk, R.R. Death following injection of neostigmine. Brit. M.J. I: 852 (1949).

9. HuLl, M. Death after neostigmine injection. Brit. M.J. 2: 601 (1949).

10. Cletron-Brock, J. Death following neostigmine. Brit. M.J. 1; 1007 (1949).

11. WAQUET, G. Curare and prostigmine, two cases of death caused by cardiac syncope after prostigmine administration. Marseille Chirurg, 3: 336-339 (1951).

12. LAwson, J.J. Cardiac arrest following the administration of neostigmine. Brtt. I. Anaesth. $28: 336-337$ (1956).

13. Poot.ta, H,E. Atropine, neostigmine and sudden death. Anaesthesia 12: $198-202$ (1957).

14. Ban, W.A. B Broadnent, J.L. Letter to the Editor, Brit. M.J. I: 1137 (1949),

15. Ovassapian, A. Effects of admintstration of atropine and neostigmine in man. Anesthesia \& Analgesia 48: 219-223 (1969).

16. Boathight, C.F, Nbwelt, R.C., Watson, R.L., \& Bafiniart, R.A. Sudden cardiac arrest in adenotonsillectomy. Tr. Am. Acad. Ophth. Otol. 74: 1139-1145 (1970).

17. McGurgaN, H. Effect of smail doses of atropine on heart rate. J.A.M.A. 76: 1838-1340 (1921).

18. Honter, A.R. Anti-curare agents, Brit. M.]. 1; 640-642 (1953).

19. Baraka, A. Safe Reversal (2): Atropine-neostigmine mixture, an electrocardiographic study. Brit. I. Anaesth. 40; 30-35 (1968).

20. De Padua, C.B. Ganvensten, J.S. Atropine stulfate vs atropine methyl bromide: effect on maternal and fetal heart rate. J.A.M.A. 208: 1022-1023 (1969). 